\title{
Die moontlikheid van Christelike onderwys in Suid-Afrika ná 1994
}

\author{
J.L. van der Walt \\ Fakulteit Opvoedkunde \\ Potchefstroomse Universiteit vir $\mathrm{CHO}$ \\ POTCHEFSTROOM
}

\section{Summary}

The possibility of Christian education in South Africa after 1994

Conditions in South Africa have become decidedly unfavourable for the continued practice of Christian education in schools. A culture of fundamental human rights has become firmly established, which, among others, has resulted in the arrival of a secular-humanist educational dispensation. The issue facing the Christian community is how to exploit the prevailing conditions for the survival of Christian education in the system. The research reported in this article has revealed that the new system hinges on four principles, and that an understanding of these principles can afford scope and latitude for Christian education. The four principles are analysed in some detail with reference to a Constitutional Court decision and recent legislation.

\section{Inleiding en probleemstelling}

In Christelike kringe was die promulgering van die Wet op Nasionale Onderwysbeleid (no. 39) in 1967 'n groot hoogtepunt, aangesien dit beskou is as 'n oorwinning oor die sekulêre, liberale, humanistiese invloede op die onderwys invloede wat sedert die $17 \mathrm{de}$ eeu in hierdie land daarop gerig was om die Christelike inslag in die onderwys teen te staan en te vemietig. Die koms van Wet 39 van 1967 het 'n nuwe bedeling in die openbare onderwys in Suid-Afrika laat aanbreek, aangesien dit vereis het dat sodanige onderwys (met name veral vir blankes) Christelik moes wees. Die veronderstelling was, hoewel nie altyd uitgesproke so gestel nie, dat die eis ook sou geld vir die ander bevolkingsgroepe in die land.

Hoewel dit hoegenaamd nie 'n uitgemaakte saak was dat die Wet daarin geslaag het om die onderwys in die praktyk volledig Christelik te stempel nie, het die Wet tog 'n Christelike vaandel oor (veral Christelike blanke) onderwys laat wapper in die periode 1967 tot 1994. Laasgenoemde datum sien die koms van 'n "nuwe" Suid-Afrika, 'n nuwe staatkundige bedeling met totaal ander onderwyswaardes as wat (veral in Christelike blanke) kringe geheers het in die periode 1967 tot 1994. 
Die periode tussen 1994 en 1996 is gekenmerk deur 'n stelselmatige aftakeling van die vorige bedeling in die onderwys, gepaardgaande met ' $n$ stadige dog sekere proses van transformasie van die onderwys. 'n Onoorsigtelike aantal insette is tot die onderwys gemaak in die vorm van forums, kommissies, afvaardigings, gesprekke, konsultasies en vele meer. In hierdie onderhandelinge was verskillende instansies uit die Christengemeenskap opvallend aktief. 'n Mens dink hier aan die bydraes van kerke, lidmate, die nasionale en provinsiale Interkerklike Komitees vir Opvoeding en Onderwys, die SA Federasie van Staatsondersteunde Skole, die SA Stigting vir Onderwys en Opleiding en verskeie meer.

Die proses van onderwystransformasie is ten tye van die skrywe van hierdie artikel (Februarie 1997) nog glad nie verby nie. Gesprekke oor verskillende aspekte van die onderwys gaan nog voort, waarvan dié oor die norme en standaarde in onderwysersopleiding, die voorgestelde leergebiede en uitkomsgerigte onderwys seker die belangrikste is. Gesprekke gaan ook voort op ander fronte soos Verdere Onderwys, Hoër Onderwys en Volwassene Basiese Onderwys, en sal seker nog 'n geruime tyd duur.

$\mathrm{Na}$ die enigsins onbevredigende afloop van die sogenaamde artikel 247onderhandelinge (Tussentydse Grondwet 1993, art. 247 - vgl. SA, 1993) tussen die Departement van Onderwys en die sogenaamde model C-skole en hulle verteenwoordigers in 1996, heers daar 'n mate van kommer in die gemoedere van Christene in die land oor die voortbestaan en oorlewing van die Christelike beginsels in die onderwys. Dié kommer heers onder alle Christene in die land, soos bewys deur die optredes van die Christian Education Forum, wat veral uit onderwysmense van die historiese swart kerke saamgestel is. Dit blyk ook uit die grootskaalse stigting van pertinent Christelike, onafhanklike skole, soos die Trinity House School in Randburg wat aan die begin van 1997 sy deure geopen het met 310 leerlinge en 23 onderwysers, die skole gestig onder die vaandel van die Aksie Reformatoriese Onderwys, en die Christelik-volkseie skole.

Die vraag of Christelike onderwys in die nuwe bedeling in die onderwys nog ruimte vir voortbestaan het, het aanleiding gegee tot die navorsing wat in hierdie artikel gerapporteer word. Die ondersoek het die volgende behels: deur middel van 'n analise van verskeie onderwysverslae, van die standpunte van belangrike onderwysgesaghebbendes, en van verskeie nuwe (onderwys-)wette wat sedert 1994 gepromulgeer is, is probeer om vas te stel wat die aard en omvang is van die ruimte wat voortaan vir Christelike onderwys beskikbaar is 
J.L. van der Walt

\section{Die ruimte vir Christelike onderwys in die nuwe onderwys- bedeling: 'n voorlopige omlyning}

Die navorsing het aan die lig gebring dat die ruimte vir Christelike onderwys in terme van vier nuwe parameters beskryf kan word. Hulle is:

- Die etos van 'n oop en demokratiese samelewing

- Die gedagte van principled consensus (beginsel-konsensus)

- Die erkenning van die individu se defensiewe regte

- Die beginsel van praktiese uitvoerbaarheid

Die ondersoek het aan die lig gebring dat die eerste twee van hierdie beginsels van die nuwe onderwysbedeling as 't ware 'n window of opportunity aan die voorstanders van Christelike onderwys bied wat benut sal moet word om sodanige onderwys in die toekoms in die land te kan voorsien. Die derde van die genoemde beginsels bied aan die pleitbesorgers vir Christelike onderwys ' $n$ alternatiewe moontlikheid om te oorweeg indien die window of opportunity vir hulle sou toegaan, terwyl die vierde beginsel duidelike beperkinge op die moontlikheid van Christelike onderwys lê. Met dié beperkinge sal voorstanders van Christelike onderwys moet reken.

In die res van hierdie artikel sal hierdie vierledige gevolgtrekking wat op grond van die navorsing gemaak is, in meer besonderhede toegelig word. Dit is egter ten aanvang nodig om die term "Christelike onderwys", 'n sleutelterm in hierdie navorsing, konseptueel nader te presiseer.

\section{Christelike onderwys}

Christelike onderwys is in die navorsing wat uitgevoer is, beskou as daardie vorm van onderwys wat gefundeer is op Bybelse beginsels soos byvoorbeeld: aan God alleen die eer; die mens word slegs op grond van sy geloof salig; die Skrif is die enigste bron van beginsels wat die lewe van die gelowige beheers; die ouer is die eerste of primêre opvoeder, en gevolglik word volledige ouerseggenskap en -betrokkenheid in die onderwys opgeëis. Die Christen-filosoof Herman Dooyeweerd (1969(I):8, 25, 64, 68 e.v., 86, 93 e.v.) het die Skriftuurlike grondmotief van Christelike onderwys saamgevat as "skepping, sondeval en verlossing deur Jesus Christus in die gemeenskap met die Heilige Gees". Hy is hierin nagevolg deur talle opvoedingsfilosowe in Suid-Afrika soos Schoeman $(1975,1979,1980)$, Van der Walt en Dekker (1982-83) en Van der Walt et al. (1983). Hierdie benadering tot onderwys is in onlangse tye baie sistematies en volledig uiteengesit en ontwikkel deur Fowler (1980, 1987, 1990, Fowler et al., 1995), Steensma (1971), Kranendonk (1978), Van Brummelen (1988), Cummings (1979 en 1982), Adams (1982), Van Dyk (1997), en vele andere, wat 'n verdere 
volledige uiteensetting daarvan in hierdie artikel oorbodig maak. Hierdie opvoedingsdenkers het die beginsels wat aan die begin van hierdie paragraaf genoem is, in groot besonderhede verduidelik, gekontekstualiseer en in die praktyk toegepas. Hulle pogings, sowel as dié van ander opvoedingsdenkers wie se name nie hier vermeld is nie, het daartoe gelei dat die begrip "Christelike onderwys" vandag op 'n omvattende opvoedingsfilosofie dui. Dit omvat die beginsels, strewes, ideale en praktyke van alle opvoeders wat hulle opvoedingsteorie en -praktyk op die grondslag van die Heilige Skrif as Woord van die Drieenige God plaas.

Twee beginsels van meer opvoedkundige aard word dikwels met Christelike onderwys geassosieer, naamlik die eis dat onderwys kultuurgerig en -begrond moet wees, en dat onderwys deur medium van die moedertaal behoort te geskied ten einde optimaal te kan verloop. Dit is egter belangrik om te besef dat hierdie twee beginsels opvoedkundig gefundeer kan word maar nie lewensbeskoulik, waaronder volledige ouerbetrokkenheid en -seggenskap, gefundeer kan word nie (vgl. Deut. 6:4-7 [Bybel, 1983] waar laasgenoemde geëis word). Die navorsing wat uitgevoer is, het gekonsentreer op Christelike onderwys soos lewensbeskoulik gefundeer (dus: Skriftuurlik, waaronder die eis van ouerseggenskap) en nie op die opvoedkundige fundering (kultuurgerigtheid waaronder die moedertaal as onderrigmedium) nie. Die laasgenoemde twee opvoedkundige beginsels kom egter ook by geleentheid ter sprake in die oorsig wat hierna volg.

\section{Twee beginsels van die nuwe onderwysbedeling bied aan Christelike onderwys 'n window of opportunity}

\subsection{Die etos van 'n oop en demokratiese samelewing bied ruimte vir Christelike onderwys}

Die Minister van Onderwys (Bengu, 1996a:4) stel dit duidelik dat die nuwe onderwysbedeling op bepaalde beginsels en voorwaardes gefundeer is. Die uitgangspunt in die verskaffing van onderwysgeleenthede is dat almal gelyk behandel sal word in die nuwe oop en demokratiese samelewing van die land. Die vorige bedeling het nie aan hierdie norm voldoen nie aangesien die meerderheid van die mense in die land nie by die proses van onderwysvoorsiening betrek was nie (Bengu, 1996a:1). Elders voer die Minister aan (Bengu \& Dey, 1996:15) dat die multikulturele en -linguale aard van die land se bevolkingsamestelling erken en benut moet word maar sê dan: "The opposite has in fact been the practice: the cultures and language of the majority of our people have been under-developed - actually downright destroyed". In 'n parlementêre begrotingstoespraak onderstreep Bengu (1996b:12) die aard van die nuwe oop en demokratiese samelewing as hy sê: : “.. we created the policy and the legislative framework for the organisation, governance and funding of our school system on 
non-racial, democratic and equitable lines ..." Hy vervolg: "The education and training system belongs to all people of this land, and, within our resources it must serve all their interests and needs equitably ..."

Die eerste Witskrif oor die onderwys in die nuwe bedeling (1995:17) het al gewag gemaak van 'n "democratically governed society" wat die kollektiewe morele perspektief van al die landsburgers moet omvat en bevorder. Die Witskrif (SA, 1995a:23) spel 23 beginsels vir onderwysvoorsiening uit, waarvan beginsel twee stel dat die onderwys en opleiding gebaseer sal word op grondliggende menseregte. Dié Witskrif (SA, 1995a:43) dui ook elders, in werklikheid deurgaans, aan dat daar in die proses van onderwysvoorsiening rekening gehou word met die Handves van Fundamentele Regte in die destydse tussentydse Grondwet (1993). Die tweede Witskrif (van 24 November 1995) het hierdie uitgangspunte soos gestel in die eerste Witskrif, bevestig.

Die koms en voortbestaan van 'n oop en demokratiese samelewing word ook sedert 1994 in wetgewing verskans. Die Grondwet (108/1996 art. 7(1)) bevestig die demokratiese waardes van menswaardigheid, gelykheid en vryheid. Gelykheid sluit die volle genieting van alle staatsburgerlike regte en vryhede in, en waar onbillik teen persone gediskrimineer word, kan mense beskerm en hulle saak bevorder word (art. 9(2)). Daar mag nie onbillik deur die staat gediskrimineer word op grond van ras, geslag, godsdiens, gewete, taal of geboortestand nie (art. 9(3)). Elkeen het die reg op vryheid van gewete, godsdiens, denke, geloof en opinie. Religieuse "observances" mag by 'n staats- of staatsondersteunde inrigting plaasvind, op voorwaarde dat die voorskrifte gevolg word wat deur die toepaslike gesagsinstansies neergelê is; dat hulle op 'n "equitable" grondslag plaasvind, en dat hulle bywoning vry en vrywillig is (art. 15(1,2)). Elke persoon het die reg tot vrye assosiasie (art. 18). Wanneer die beginsels van die Handves van Fundamentele Regte bepaal moet word, moet ' $n$ hof, forum of tribunaal die waardes wat 'n oop en demokratiese samelewing ten grondslag lê, bevorder (39(1)).

Die Wet op Nasionale Onderwysbeleid (27/1996) het ten doel die demokratiese omskepping van die nasionale onderwysstelsel tot 'n stelsel wat in die behoeftes voorsien en die belange dien van al die mense in Suid-Afrika, en wat hulle fundamentele regte handhaaf (Aanhef - vgl. SA, 1996b). Die bepalings van die Wet is in ooreenstemming met die eise van die Grondwet (art. 3(1)), insluitende die beskerming van fundamentele regte (art. 4(a)), soos die vryheid van gewete, godsdiens, geloof, mening, opinie en assosiasie in onderwysinrigtings. Die $S A$ Skolewet (84/1996) gee weerklank aan hierdie selfde sentimente: die onderwys moet die demokratiese transformasie van die gemeenskap bevorder, en die regte van alle leerders, ouers en opvoeders handhaaf (Aanhef - vgl. SA, 1996c). Die beoefening van godsdienstige praktyke en vryheid van gewete moet volgens die 
voorskrifte van 'n betrokke skool se beheerliggaam geskied, en is slegs toelaatbaar indien die beoefening daarvan op 'n billıke wyse geskied, en die bywoning daarvan deur leerders en personeellede vry en vrywillig is (art. 7). Die Wet maak voorts voorsiening vir sowel openbare as onafhanklike skole (art. 45), en onder bepaalde omstandighede ook vir tuisonderwys (art. 51).

\subsection{Principled consensus bied ruimte vir die uitlewing van Christelike onderwysbeginsels}

Onderwysminister Bengu (1996b:2,5; Bengu \& Mashige, 1996d:49) maak gewag van die beleid van principled consensus in die vasstelling van riglyne vir die onderwys(stelsel) van die land. Die konsensus waarna hy verwys, is gebaseer op 'n aantal beginsels voortkomend uit die demokrasie. Hierdie beginsels sluit onder meer die volgende, as kenmerkend van 'n oop en demokratiese samelewing, in: gelyke toegang tot die onderwys aan alle mense, die strewe na goeie gehalteonderwys, die diversifiëring van die onderwys sodat elkeen die vorm van onderwys kan ontvang waarna hy/sy streef, voorsiening in die eise van die ekonomie van die land, aanwending van bronne op 'n wyse wat gelyke leergeleenthede bied, die evaluering en monitering van kwalifikasies, doeltreffendheid, produktiwiteit en kostedoeltreffendheid (Bengu, 1996b:2-3). Die onderwys moet voorts doelgerig bestuur word volgens die beginsels wat hier vermeld word (Bengu \& Mashige, 1996:49). Bengu en Dey (1996:15) stel ook die erkenning en die bevordering van die veelkulturigheid en -taligheid in die bevolking as ' $n$ beginsel in onderwysvoorsiening (met die versweê moontlikheid dat hulle ook die veelgodsdienstigheid daarvan by die veelkulturigheid inreken). Ander beginsels wat hulle stel, is nie-rassigheid, en 'n demokratiese en "equitable" benadering tot die onderwys (Bengu, 1996b:2). Volgens Bengu (1996b:5) streef hy daarna "to build the highest level of principled consensus in the development and execution of the government's policy for educational transformation (...) The education system belongs to all people of this land, and, within our resources it must serve all their interests and needs equitably, efficiently, and with total dedication to quality performance".

In Witskrif I (15 Maart 1996:17) word principled consensus in meer besonderhede verduidelik:

In a democratically governed society, the education system as a whole embodies and promotes the collective moral perspectives of its citizens, that is the code of values by which the society wishes to live and consents to be judged ... (...) ... in our era (history) has culminated in historical agreement based on the recognition of the inalienable worth, dignity and equality of each person under the law, mutual tolerance and respect for diversity. In the Charter of Fundamental Rights and the schedule of Constitutional Principles the ... Constitution expresses a moral view of human beings and 
the social order which will guide policy and law-making in education as in all sectors (...) the Constitution provides ... a future founded on the recognition of human rights, democracy and peaceful co-existence and development opportunities for all South Africans, irrespective of colour, race, class, belief and sex (vgl. SA, 1995a).

Witskrif II (24 November 1995:12) herhaal hierdie beginselgrondslag maar voeg ook die beginsel van 'n vennootskap tussen die staat en die plaaslike gemeenskap daaraan toe. Dit onderstreep ook die erkenning van ouerregte in die onderwys (24 November 1995:20), terwyl dit ook die belang van ander rolspelers in die skool en onderwys erken (SA, 1995b:21).

Ook die wetgewing wat uit die twee Witskrifte voortgevloei het, gee erkenning aan die lys van beginsels waaroor die burgery in 'n demokratiese samelewing eenstemmig behoort te wees (vgl. Wet 27/1996, art. 2), terwyl die SA Skolewet (84/1996: Aanhef) die beginsels wat onderwysvoorsiening in die demokratiese bedeling wat aangebreek het ten grondslag lê, kortliks saamvat: regstelling van onregte in die verlede, goeie gehalteonderwys moet voorsien word, al die mense se bekwaamhede en talente moet ontwikkel word, demokratiese transformasie van die gemeenskap moet bevorder word, onregverdige diskriminasie moet bekamp word, die verskeidenhede van tale en kulture moet beskerm word, die regte van rolspelers in die onderwys moet gehandhaaf word, en skole moet in vennootskap met die staat bestuur word. Die Wet moet ook eenvormige standaarde vir alle onderwys in die land neerlê.

\subsection{Dié twee beginsels bied ruimte vir die voortgesette beoefening van Christelike onderwys}

Die ontleding van uitsprake van historiese maghebbers in die onderwys, van uitsprake in amptelike regeringsdokumente, en van bepalings in die tersaaklike wetgewing, het aan die lig gebring dat daar inderdaad heelwat ruimte ('n window of opportunity) vir die voortgesette beoefening van Christelike onderwys in die land bestaan. Daar is klaarblyklik geen beletsel in die weg van Christene, as individue of as gemeenskap, om onderwys volgens hulle Bybelse oortuigings aan hulle kinders te bied nie. Die beginsels van 'n oop en demokratiese samelewing maak dit moontlik om die oortuigings wat Christenmense huldig, met oorgawe, sonder verhindering en sonder enige vorm van diskriminasie in die alledaagse praktyk van die onderwys uit te leef.

Daar is egter nog twee ander beginsels vir onderwysvoorsiening wat bepalend is vir die ruimte wat vir die uitlewing van Christelike onderwysbeginsels beskikbaar is. 


\subsection{Die erkenning van burgers van die land se defensiewe regte}

Die twee beginsels wat tot dusver beskryf is, is positief van aard. Hulle beskryf in positiewe terme wat die moontlikhede en die geleenthede is wat deur die burgers van die land benut kan word in die uitlewing van hulle oortuigings in onderwysvoorsiening en -strukture. Die derde beginsel is egter negatief van aard, in die sin dat dit die defensiewe regte van burgers beskryf. Hierdie soort regte kom in spel wanneer ' $n$ individu of ' $n$ gemeenskap tot die slotsom gekom het dat geleenthede en strukture wat die staat/owerheid bied nie aan die betrokke individu of gemeenskap se behoeftes kan voorsien nie, of nie aan hulle spesifieke eise kan voldoen nie

Die uitspraak van die Grondwetlike Hof (saak no. CCT 39/95) is in hierdie verband van sleutelbelang (Constitutional Court of SA, 1996). Regter Mahomed sê in sy uitspraak dat dit nie van die staat verwag kan word om onderwysinrigtings te voorsien wat gebaseer is op 'n bepaalde gemeenskaplike kultuur, taal of godsdiens nie. Die Grondwet voorsien die reg aan elke persoon om self so 'n onderwysinstansie van sy of haar keuse op te rig. Hierdie is 'n defensiewe reg wat deur die Grondwet voorsien en beskerm word. Die staat het geen bevoegdheid om hierdie defensiewe reg in die gedrang te bring nie. Regter Kriegler stem in sy uitspraak hiermee saam as hy aanvoer:

Die Grondwet hou daarmee die deur oop vir diegene vir wie die staat se onderwysinstellinge ontoereikend geag word wat betref gemeenskaplike kultuur, taal of godsdiens. (...) Daar is egter 'n prys, naamlik dat so 'n bevolkingsgroep daarvoor die hand in eie sak moet steek.

Regter Sachs sê in sy uitspraak dat die Grondwet die staat verplig om beskerming te verleen aan die voorregte (privileges) van minderhede. Die staat moet minderhede se reg nie slegs erken nie, maar dit ook ondersteun.

Visser (1996:3) gebruik die term offensief om daarmee te dui op aanvalle wat byvoorbeeld deur Christene op verkeerde leringe in die nuwe onderwysbedeling geloods kan word. Daarteenoor gebruik hy die term defensief wanneer Christelike beginsels deur byvoorbeeld die onderwysowerheid aangeval of bedreig sou word. In die konteks van die uitspraak van die Grondwetlike Hof beteken dit dat Christene, as individue en as gemeenskap, hulle reg kan uitoefen om eie onderwysinrigtings soos skole te stig en te onderhou indien hulle nie tevrede is met die grondslag en die beginsels (etos) van byvoorbeeld die skole wat deur die staat voorsien word nie.

Die defensiewe reg van minderhede word ook in die onderwyswetgewing erken en verskans. Wet 27 van 1996 beskerm byvoorbeeld in artikel 4(a) die fundamentele regte van elke burger van die land, en vrywaar hom/haar teen onbillike diskriminasie deur ' $n$ ondenwysdepartement of -inrigting. Wet 84 van 
1996 stel op sy beurt (art. 4(1)) dat 'n departementshoof 'n leerder heeltemal, gedeeltelik of voorwaardelik van verpligte skoolbywoning kan vrystel indien dit in die beste belang van die leerder geag word (vgl. ook art. 51). Hoofstuk 5 maak in sy geheel voorsiening vir onafhanklike skole, voorheen bekend as "privaatskole", wat volledig of met staatsubsidie deur die oprigter(s) daarvan opgerig en in stand gehou moet word (vgl. Wet 108 van 1996). Die erkenning in die Wet van hierdie kategorie skole is ' $n$ regstreekse uitvloeisel van die defensiewe reg van individue en gemeenskappe (minderhede) om 'n eie alternatief te voorsien en te bekostig indien hulle nie met die opsies tevrede is wat die staat voorsien nie. Visser (1996:6) wys voorts op die moontlikheid om 'n defensiewe reg uit te oefen deur toepassing van die "strategie om (wettig) 'n tipe privaatskool binne ' $n$ openbare skool te bedryf ten einde die behoeftes van Christelike kinders beter te kan akkommodeer".

\subsection{Die beginsel van praktiese uitvoerbaarheid}

In teenstelling met die beginsels wat in $4.1,4.2$ en 4.4 behandel is, plaas hierdie vierde beginsel of uitgangspunt van die nuwe onderwysbedeling ' $n$ besliste beperking op die moontlikheid om Christelike onderwys in openbare skole te verkry. Hierdie beperking dwing die Christengemeenskap om sy defensiewe regte (kyk 4.4) as alternatiewe uitweg uit te oefen. Die beginsel van praktiese uitvoerbaarheid is sterk werksaam in die 1996-wetgewing.

Die Grondwetlike Hofuitspraak (nr. CCT. 39/95) sê dat minderhede hulle defensiewe reg kan uitoefen mits dit prakties uitvoerbaar geag word (p. 6, 7 en 9 van die Uitspraak). Indien dit nie die geval is nie kan minderhede nie verwag dat die Grondwet hulle teen 'n reeling van die staat moet beskerm nie. Die Grondwet (108 van 1996) stel dit ook dat enkelmediumskole deur die staat oorweeg moet word waar dit prakties uitvoerbaar is. 'n Mens kan deur 'n proses van inferensie aflei dat dit ook die geval met godsdienstige oortuiging sal wees; daarom maak die Grondwel (art. 29(3) en (4)) voorsiening vir die defensiewe reg om eie onderwysinrigtings op te rig en hulle self (ook met staatsubsidie) in stand te hou.

Hierdie gedagte van redelike uitvoerbaarheid kom ook voor in Wet 27 van 1996 (art. 4(a)). Artikel $4(4 \mathrm{~m})$ van die Wet bring uitvoerbaarheid in verband met kostedoeltreffendheid en volhoubaarheid met die beskikbare hulpbronne. Die $S A$ Skolewet (84/1996) maak nie in dieselfde mate gebruik van die beginsel van praktiese uitvoerbaarheid nie. Die verklaring daarvoor lê opgesluit in die feit dat die Skolewet gesien moet word teen die agtergrond van die Grondwet (108/1996) en die Wet op Nasionale Onderwysheleid (27/1996) waarin die beginsel reeds ondubbelsinnig gestel is. 


\section{Slotsom}

Die Christengemeenskap in Suid-Afrika, soos elders in die wêreld, is diep besorg oor die behoud van die Christelike beginsel in die onderwys. As ideaal word deur hierdie gemeenskap gestel dat alle skole getrou aan die beginsel moet wees. Die werklikheid is egter anders: alle skole kan nie daaraan getrou wees nie, veral nie openbare of staatskole nie aangesien hulle moet voorsien in die behoeftes van alle godsdienstige gemeenskappe in die land. Die netto-resultaat hiervan is dat die openbare skoolstelsel neutraal-sekulêr moet wees aangesien dit aan alle gemeenskappe se behoeftes moet voldoen

Die neutraal-sekulêre onderwysbedeling maak egter voorsiening vir positiewe ruimte vir die beoefening van die Christelike beginsel in die onderwys (vgl. 4.1 en 4.2 hierbo): die oop en demokratiese samelewing vereis dat die fundamentele regte van alle individue erken sal word, en dit veronderstel ook ' $n$ aantal waardes en beginsels waaroor burgerlike konsensus verkry is. Die nuwe bedeling maak ook voorsiening vir die erkenning van die defensiewe regte van Christene as individue en as gemeenskap. Die pragmatiese beginsel van praktiese uitvoerbaarheid lê egter duidelike beperkinge op die uitoefening van hierdie defensiewe regte sowel as op die uitoefening van minderheidsregte binne die raamwerk van 'n oop en demokratiese samelewing, en van die principled consensus wat daarop rus.

Die algemene slotsom waartoe 'n mens kan kom, is dat elke Christenonderwysbelanghebbende hierdie vier beginsels van die huidige onderwysvoorsiening deeglik moet ken en verstaan, en binne die konteks daarvan 'n eie strategie moet bepaal en beplanning moet doen ter wille van die behoud van Christelike onderwys. 'n Poging hiertoe is reeds deur Visser (1996) aangewend.

\section{Bronnelys}

ADAMS, J.E. 1982. Back to the black-board. Phillipsburg : Presbyterian and Reformed Publishing Company.

BENGU, S.M.E. 1996a. Speech by Prof Bengu. Education Association of South Africa, 17 January 1996. Potchefstroom.

BENGU, S.M.E. 1996b. Debate on the education budget vote in the National Assembly, 21 May 1996.

BENGU, S.M.E. \& DEY, L. 1996. Honourable Minister, the question is ... The Educator: 15-18, Nov./Dec.

BENGU, S.M.E. \& MASHIGE, S. 1996. Honourable Minister, the question is ... The Educator: 49-53, Nov./Dec.

BYBEL 1983. Die Bybel: nuwe vertaling. Kaapstad : Bybelgenootskap van Suid-Afrika

CONSTITUTIONAL COURT OF SOUTH AFRICA 1996. In re: Dispute concerning the constitutionality of certain provisions of the School Education Bill of 1995. Case no. CCT 39/95. 4 April 1996.

CUMMINGS, D. B ed 1979 The purpose of a Christian school Phillipsburg : Presbyterian and Reformed Publishing Company 
J.L. van der Walt

CUMMINGS, D B ed. 1982. The basis for a Christian school. Phillipsburg : Presbyterian and Reformed Publishing Company.

DOOYEWEERD, H 1969(1). A new critique of theoretical thought. Phillipsburg Presbyterian and Reformed Publishing Company

FOWLER, S. 1980. Issues in the philosophy of education Potchefstroom : IRS

FOWLER, S. 1987. Christian educational distinctives. Potchefstroom : IRS

FOWLER, S. 1995. The oppression and liberation of modern Africa. Potchefstroom : IRS

FOWLER, S., VAN BRUMMELEN, H \& VAN DYK, J. 1990. Christian schooling: Education for freedom. Potchefstroom : IRS.

KRANENDONK, D.L. 1978. Christian day schools. St. Catherines : Paideia Press.

SA

$k y k$

Suid-Afrika

SCHOEMAN, P G. 1975. Grondslae en implikasies van 'n Christelike opvoedingsfilosofie Bloemfontein Sacum

SCHOEMAN, P.G. 1979. Aspekte van die wysgerige pedagogiek Bloemfontein : Sacum

SCHOEMAN, P.G 1980. Introduction to a philosophy of education. Durban : Butterworth.

STEENSMA, G.J. 1971. To those who teach Signal Mountain : Signal Press

SUID-AFRIKA. 1993. Tussentydse Grondwet. Pretoria : Staatsdrukker

SUID-AFRIKA. Departement van Onderwys. 1995a. White paper on education and training. (WPJ-1995.) Staatskoerant. 16312, Maart 15

SUID-AFRIKA. Departement van Onderwys. 1995b The organisation, governance and funding of schools: A draft policy document for discussion. (Draft Education White Paper 2.) Staatskoerant, 365 (16839). Kennisgewing 1229 van 1995.

SUID-AFRIKA. 1996a. Constitution of the Republic of South Africa (no. 108 van 1996). Staatskoerant, 378 (17678).

SUID-AFRIKA. 1996b. Wet op Nasionale Onderwysbeleid (no. 27 van 1996). Staatskoerant, 370 (17118).

SUID-AFRIKA. 1996c. Suid-Afrikaanse Skolewet (no. 84 van 1996). Staatskoeramt, 377 (17579).

VAN BRUMMELEN, H. 1988. Walking with God in the classroom. Christian approaches to teaching and learning. Burlington: Welch Publishing Company.

VAN DER WALT, J.L. \& DEKKER, E.I. 1982-3. Fundamentele opvoedkunde vir onderwysstudente. Silverton : Promedia.

VAN DER WALT, J L., DEKKER, E.I \& VAN DER WALT, I D. 1983. Die opvoedingsgebeure: 'n Skrifmatige perspektief. Potchefstroom : PU vir CHO.

VAN DYK, J. 1997. Letters to Liza. Conversations with a Christian teacher. Sioux Center : Dortdt Press.

VISSER, P.J. 1996. Gedagtes oor strategie en taktiek vir Christene met betrekking tot die Christelike geloof in die skoolsituasie. (Ongepubliseerde verslag aan die IKOO, Pretoria.) 